\title{
Interpretation of serum calcitonin in patients with chronic autoimmune thyroiditis
}

\author{
Giorgio Grani, Angela Nesca, Marianna Del Sordo, Anna Calvanese, \\ Giovanni Carbotta, Marta Bianchini and Angela Fumarola
}

Unit of Endocrinology, Department of Experimental Medicine, 'Sapienza' Università di Roma, V.le Regina Elena, 324, 00161 Rome, Italy

(Correspondence should be addressed to A Fumarola; Email: angela.fumarola@uniroma1.it)

\begin{abstract}
Calcitonin (CT) is an important clinical marker for the diagnosis and follow-up of medullary thyroid carcinoma, although it is not absolutely specific. Some authors have reported C-cell hyperplasia in a number of thyroid specimens affected by Hashimoto's thyroiditis. The association between thyroiditis and hypercalcitoninemia is still controversial because some authors have reported low CT levels. The aim of this study is to evaluate the basal CT values in patients with and without thyroid autoimmunity. From May 2005 to February 2010, 1073 patients underwent ultrasonography-guided fine-needle aspiration cytology at the Thyroid Center of Sapienza University of Rome, with evaluation of basal serum FT4, FT3, TSH, and antithyroid peroxidase (anti-TPO) antibodies as well as CT levels. Forty-one patients presented a basal CT level above the reference upper limit. The mean serum CT was significantly lower in women than in men $(4.28 \pm 6.63$ vs $7.50 \pm 25.50 \mathrm{pg} / \mathrm{ml} ; P<0.01)$. Basal serum CT was not significantly higher in patients showing anti-TPO Ab positivity $(4.71 \pm 6.46 \mathrm{vs} 4.84 \pm 13.11 \mathrm{pg} / \mathrm{ml} ; P>0.05)$. Importantly, the rate of 'suspicious' CT values (above the $10 \mathrm{pg} / \mathrm{ml}$ cutoff) was not significantly different between patients with or without thyroid autoimmunity (3.9 vs $3.0 \%$ ). Patients with hypercalcitoninemia suffering from chronic autoimmune thyroiditis should undergo the same clinical evaluation procedure as patients do without thyroid autoimmunity.
\end{abstract}

Endocrine-Related Cancer (2012) 19 345-349

\section{Introduction}

Calcitonin (CT) is a hormone secreted by the parafollicular cells ( $\mathrm{C}$ cells) of the thyroid gland. The physiological action of this hormone is uncertain; however, pharmacologically it decreases bone resorption and lowers serum calcium. It is an important clinical marker for the diagnosis and follow-up of medullary thyroid carcinoma (MTC), although it is not absolutely specific. Elevated serum CT levels are usually caused by underlying MTC or C-cell hyperplasia $(\mathrm{CCH})$, a condition defined as the presence of more than $50 \mathrm{C}$-cells per microscope field $(\times 100)$ in both thyroid lobes (Scheuba et al. 2009) and of uncertain biological behavior. Various factors can influence CT secretion, i.e. physiological (sex, old age, and cigarette smoking; Tabassian et al. 1989, D'Herbomez et al. 2007) and pharmacological (consumption of proton-pump inhibitors, glucocorticoids, and $\beta$-blockers; Toledo et al. 2009). Moreover, several pathological conditions can cause hypercalcitoninemia, e.g. small-cell lung carcinoma, breast cancer, neuroendocrine tumors, chronic renal failure, pernicious anemia, Zollinger's syndrome, pancreatitis, hyperparathyroidism, follicular thyroid tumors (Niccoli et al. 1996), micropapillary thyroid carcinoma (Elisei 2008), and sepsis (Becker et al. 2010). Some authors have reported $\mathrm{CCH}$ in a number of thyroid specimens affected by Hashimoto's thyroiditis (Guyetant et al. 1994). However, the association between thyroiditis and hypercalcitoninemia is still controversial (Karanikas et al. 2004, Schuetz et al. 2006) because some authors have reported decreased CT levels - in smaller groups of patients - that are probably caused by atrophy, fibrosis, and destruction of 
both follicular and C-cells (Body et al. 1986, Borges et al. 1998, Lima et al. 1998, Poppe et al. 1999). In addition to this, falsely high CT levels (or spurious hypercalcitoninemia) can be caused by the presence of heterophilic antibodies; this effect can be avoided through dilution techniques or sera pretreatment with blocking reagents (Giovanella \& Suriano 2011).

\section{Materials and methods}

From May 2005 to February 2010, 1073 patients underwent ultrasonography-guided fine-needle aspiration cytology (FNAC) at the Thyroid Center of Sapienza University of Rome. The patients aged $55.70 \pm 13.41$ years (mean \pm s.D.) and all resided in Central Italy, an area of mild to moderate iodine deficiency. Male and female patients were age matched: 180 men aged $55.82 \pm 13.72$ years, while 893 women aged $55.67 \pm 13.35$ years (Table 1 ). Thyroid volume was determined by two-dimensional ultrasonography and calculated by the ellipsoid volume formula with $\pi / 6(0.524)$ as correction factor. Glands with an estimated volume $<5 \mathrm{ml}$ were considered atrophic, while thyroid volume $>16 \mathrm{ml}$ was diagnosed as goiter. All patients had at least one discrete nodular lesion of the thyroid or a multinodular goiter and were referred to our institution to undergo FNAC because of clinical or ultrasonographic suspicion (irregular margins, microcalcifications, and chaotic pattern vascularization).

The current approach at our center is to evaluate basal serum FT4, FT3, TSH, and antithyroid peroxidase (anti-TPO) antibodies as well as CT levels in all patients in the fasted state. Should suspicious serum

Table 1 Age and thyroid status data

\begin{tabular}{|c|c|}
\hline Age (years) ${ }^{\mathrm{a}}$ & $55.70 \pm 13.41$ \\
\hline Males $(n=180)^{\mathrm{a}}$ & $55.82 \pm 13.72$ \\
\hline Females $(n=893)^{\mathrm{a}}$ & $55.67 \pm 13.35$ \\
\hline \multicolumn{2}{|l|}{ Thyroid function } \\
\hline Euthyroidism & $809(75.40 \%)$ \\
\hline Subclinical hypothyroidism & $78(7.27 \%)$ \\
\hline Subclinical hyperthyroidism & $186(17.33 \%)$ \\
\hline \multicolumn{2}{|l|}{ Thyroid autoimmunity } \\
\hline Anti-TPO antibodies + & $208(19.38 \%)$ \\
\hline Anti-TPO antibodies - & $865(80.62 \%)$ \\
\hline \multicolumn{2}{|l|}{ Basal serum CT } \\
\hline Under the cutoff & $1032(96.18 \%)$ \\
\hline Age (years) $^{\mathrm{a}}$ & $55.72 \pm 13.42$ \\
\hline Above the cutoff & $41(3.82 \%)$ \\
\hline Age $\left(\right.$ years) ${ }^{a}$ & $55.17 \pm 13.20$ \\
\hline \multicolumn{2}{|l|}{ Of which } \\
\hline Pathological hypercalcitoninemia & $7(17.07 \%)$ \\
\hline Idiopathic hypercalcitoninemia & $34(82.93 \%)$ \\
\hline
\end{tabular}

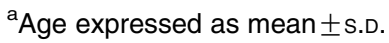

CT levels be detected, the pathologist is thereby asked to perform immunocytochemical staining for CT and chromogranin. Thyroid functional status was evaluated according to TSH levels: euthyroid between 0.4 and $2.5 \mathrm{mU} / \mathrm{l}$, hypothyroid $>2.5 \mathrm{mU} / \mathrm{l}$, and hyperthyroid $<0.4 \mathrm{mU} / \mathrm{l}$. Serum CT was determined using an automated two-site immunochemiluminometric assay, with functional sensitivity of $2.00 \mathrm{pg} / \mathrm{ml}$ and a reference upper limit of $10.00 \mathrm{pg} / \mathrm{ml}$. Anti-TPO antibodies were measured using RIAs and were considered positive if it is above the cutoff point set by the laboratory $(>50 \mathrm{U} / \mathrm{ml})$. In patients with positive anti-TPO $\mathrm{Ab}$, the mean serum TSH value is found to be significantly higher ( $1.40 \mathrm{vs} 1.13 \mu \mathrm{U} / \mathrm{ml} ; P=0.001)$ than in patients with negative antibodies. Cytology results were reported in five categories as follows, according to the British Thyroid Association Guidelines and the Thyroid Cytology Italian Consensus SIAPEC-IAP (Fadda et al. 2010): 1) nondiagnostic, 2) benign, 3) indeterminate, 4) probably malignant, and 5) positive for malignant cells.

\section{Statistical analysis}

The distribution of CT values was not normal. CT levels were compared using the Mann-Whitney $U$ test (between two groups) and Kruskal-Wallis test (more than two groups). Categorical variables were compared using Pearson's $\chi^{2}$ test. All tests used a two-sided $\alpha$ of 0.05 .

\section{Results}

Forty-one patients presented a basal CT level above the reference upper limit. In seven cases, a pathological cause of hypercalcitoninemia was found: two underwent total thyroidectomy with a final histological diagnosis of MTC (basal CT 141 and $91.1 \mathrm{pg} / \mathrm{ml}$ ), two were chronic renal failure patients requiring hemodialysis treatment (basal CT 275 and $195 \mathrm{pg} / \mathrm{ml}$ ), one had been diagnosed with MEN but refused thyroidectomy (basal CT $81.9 \mathrm{pg} / \mathrm{ml}$ ), and the remaining one had a pulmonary carcinoid tumor (basal CT $52.7 \mathrm{pg} / \mathrm{ml}$ ). Another patient had thyroid follicular adenoma (basal CT $16.3 \mathrm{pg} / \mathrm{ml}$ ), but no $\mathrm{CCH}$ was described during histological examination. The other 34 cases remained unexplained, but only two patients were found to have persistent hypercalcitoninemia during the follow-up (12 and 36 months). These two patients refused to undergo surgery and no other cause was found: atrophic gastritis, hypergastrinemia, hypercalcemia, and PPI drugs therapy were ruled out. 
Among the 34 cases of idiopathic hypercalcitoninemia, eight $(23.5 \%)$ showed thyroid autoimmunity. This rate is not significantly higher than the frequency of autoimmunity in the entire group $(19.38 \% ; P>0.05)$. Ultrasonography showed a goiter with heterogeneous echotexture in 22 cases $(64.7 \%)$ and an atrophic gland in two cases $(5.88 \%)$.

The overall mean serum CT value was 4.82 $\pm 12.11 \mathrm{pg} / \mathrm{ml}$. Not including the seven pathological hypercalcitoninemia patients, the mean value decreased to $4.05 \pm 3.49 \mathrm{pg} / \mathrm{ml}$. As expected, the serum CT mean is significantly lower in women than in men $(4.28 \pm 6.63$ vs $7.50 \pm 25.50 \mathrm{pg} / \mathrm{ml} ; P<0.01)$.

This finding is confirmed even if the seven cases are excluded from evaluation (mean basal CT $3.96 \pm 3.42$ vs $4.51 \pm 3.80 \mathrm{pg} / \mathrm{ml} ; P<0.01)$. Despite several reports (D'Herbomez et al. 2007, Toledo et al. 2009) that described increased serum CT levels in elderly patients, these data did not display a higher mean value with increasing age. Mean serum CT did not differ according to cytology results, grouped as suggested by British Thyroid Association Guidelines. It should be noted that Thy 4 and Thy 5 categories indiscriminately include suspicion of papillary, medullary, or anaplastic carcinoma, or lymphoma without specification. The rate of 'suspicious' CT values (above the $10 \mathrm{pg} / \mathrm{ml}$ cutoff) was not different between patients with or without thyroid autoimmunity (3.9 vs $3.0 \% ; P>0.05)$. Due to the high prevalence of thyroid autoimmunity in females, data were reanalyzed including only women to minimize gender-related bias: CT values above the cutoff were recorded in 3.4\% of patients with autoimmunity and in $3.1 \%$ of patients without anti-TPO Ab positivity $(P>0.05)$. Moreover, basal serum CT was not significantly higher in patients showing anti-TPO Ab positivity $(4.71 \pm 6.46$ vs 4.84 $\pm 13.11 \mathrm{pg} / \mathrm{ml} ; P>0.05$ ). These observations remain valid when the seven pathological cases of high CT levels are excluded $(4.34 \pm 3.59$ vs $3.98 \pm 3.46 \mathrm{pg} / \mathrm{ml}$; $P>0.05)$ and when only women are considered $(4.00 \pm 3.12$ vs $3.95 \pm 3.49 \mathrm{pg} / \mathrm{ml} ; P>0.05)$.

No difference was recorded in mean serum CT between patients with goiter or with atrophic gland respectively ( $3.84 \pm 3.49$ vs $5.10 \pm 5.20 \mathrm{pg} / \mathrm{ml} ; P>0.05)$. Results are summarized in Table 2.

\section{Discussion}

Routine serum CT screening is useful in patients undergoing thyroid nodule evaluation, particularly in the presence of suspicious cytological findings (Elisei et al. 2004, Papi et al. 2006, Costante et al. 2007) and appears to be cost-effective (Cheung et al. 2008). CT levels $>100 \mathrm{pg} / \mathrm{ml}$ are widely considered an indication for surgery (Kloos et al. 2009). The management of patients showing a slight increase in CT levels (a condition that is relatively more frequent) appears to be more controversial. In this study, the prevalence of MTC is only $0.19 \%$, while basal serum CT levels above the reference range were recorded in $3.82 \%$ of cases. A number of causes of spurious hypercalcitoninemia can be ruled out by obtaining a careful clinical history. Male gender and reevaluation with dilution techniques or sera pretreatment in blocking tubes must

Table 2 Basal serum calcitonin ( $\mathrm{pg} / \mathrm{ml}$, mean \pm s.D.) in subgroups of patients

\begin{tabular}{|c|c|c|c|c|}
\hline & $\begin{array}{l}\text { All patients } \\
(n=1073)\end{array}$ & $\boldsymbol{P}$ & $\begin{array}{l}\text { Patients without recognized } \\
\text { pathological increase in } \\
\text { serum CT }(n=1066)\end{array}$ & $P$ \\
\hline \multicolumn{5}{|l|}{ Sex } \\
\hline Male & $7.50 \pm 25.50$ & \multirow[t]{2}{*}{$<0.01^{a}$} & $4.51 \pm 3.80$ & \multirow[t]{2}{*}{$<0.01^{\mathrm{a}}$} \\
\hline Female & $4.28 \pm 6.63$ & & $3.96 \pm 3.42$ & \\
\hline \multicolumn{5}{|l|}{ Age } \\
\hline$<65$ years & $4.37 \pm 6.71$ & \multirow[t]{2}{*}{$>0.05^{\mathrm{a}}$} & $4.07 \pm 3.57$ & \multirow[t]{2}{*}{$>0.05^{\mathrm{a}}$} \\
\hline$\geq 65$ years & $5.96 \pm 20.09$ & & $3.99 \pm 3.27$ & \\
\hline \multicolumn{5}{|l|}{ TPO } \\
\hline Negative & $4.84 \pm 13.11$ & \multirow[t]{2}{*}{$>0.05^{a}$} & $3.98 \pm 3.46$ & \multirow[t]{2}{*}{$>0.05^{\mathrm{a}}$} \\
\hline Positive & $4.71 \pm 6.46$ & & $4.34 \pm 3.59$ & \\
\hline \multicolumn{5}{|l|}{ Cytology } \\
\hline Thy 1 & $4.86 \pm 14.64$ & \multirow[t]{5}{*}{$>0.05^{b}$} & $3.97 \pm 3.47$ & \multirow[t]{5}{*}{$>0.05^{b}$} \\
\hline Thy2 & $4.57 \pm 8.95$ & & $4.14 \pm 3.61$ & \\
\hline Thy3 & $3.58 \pm 1.95$ & & $3.58 \pm 1.95$ & \\
\hline Thy4 & $3.65 \pm 2.38$ & & $3.65 \pm 2.38$ & \\
\hline Thy5 & $47.82 \pm 64.74$ & & $2.33 \pm 0.58$ & \\
\hline
\end{tabular}

aMann-Whitney $U$ test.

${ }^{\mathrm{b}}$ Kruskal-Wallis test. 
be considered when evaluating borderline values. Nevertheless, Hashimoto's thyroiditis does not influence basal CT levels, when measured with a sensitive two-site ILMA assay. Patients with hypercalcitoninemia suffering from chronic autoimmune thyroiditis should undergo the same clinical evaluation procedure as do patients without thyroid autoimmunity.

\section{Declaration of interest}

The authors declare that there is no conflict of interest that could be perceived as prejudicing the impartiality of the research reported.

\section{Funding}

This research did not receive any specific grant from any funding agency in the public, commercial, or not-for-profit sector.

\section{References}

Becker KL, Snider R \& Nylen ES 2010 Procalcitonin in sepsis and systemic inflammation: a harmful biomarker and a therapeutic target. British Journal of Pharmacology 159 253-264. (doi:10.1111/j.1476-5381.2009.00433.x)

Body JJ, Demeester-Mirkine N, Borkowski A, Suciu S \& Corvilain J 1986 Calcitonin deficiency in primary hypothyroidism. Journal of Clinical Endocrinology and Metabolism 62 700-703. (doi:10.1210/jcem-62-4-700)

Borges MF, Abelin NM, Menezes FO, Dahia PL \& Toledo SPA 1998 Calcitonin deficiency in early stages of chronic autoimmune thyroiditis. Clinical Endocrinology 49 69-75. (doi:10.1046/j.1365-2265.1998.00478.x)

Cheung K, Roman SA, Wang TS, Walker HD \& Sosa JA 2008 Calcitonin measurement in the evaluation of thyroid nodules in the United States: a cost-effectiveness and decision analysis. Journal of Clinical Endocrinology and Metabolism 93 2173-2180. (doi:10.1210/jc.2007-2496)

Costante G, Meringolo D, Durante C, Bianchi D, Nocera M, Tumino S, Crocetti U, Attard M, Maranghi M, Torlontano M et al. 2007 Predictive value of serum calcitonin levels for preoperative diagnosis of medullary thyroid carcinoma in a cohort of 5817 consecutive patients with thyroid nodules. Journal of Clinical Endocrinology and Metabolism 92 450-455. (doi:10.1210/jc.2006-1590)

D'Herbomez M, Caron P, Bauters C, Do Cao C, Schlienger JL, Sapin R, Baldet L, Carnaille B \& Wemeau JL 2007 Reference range of serum calcitonin levels in humans: influence of calcitonin assays, sex, age, and cigarette smoking. European Journal of Endocrinology 157 749-755. (doi:10.1530/EJE-07-0566)

Elisei R 2008 Routine serum calcitonin measurement in the evaluation of thyroid nodules. Best Practice \& Research. Clinical Endocrinology \& Metabolism 22 941-953. (doi:10.1016/j.beem.2008.09.008)
Elisei R, Bottici V, Luchetti F, Di Coscio G, Romei C, Grasso L, Miccoli P, Iacconi P, Basolo F, Pinchera A et al. 2004 Impact of routine measurement of serum calcitonin on the diagnosis and outcome of medullary thyroid cancer: experience in 10,864 patients with nodular thyroid disorders. Journal of Clinical Endocrinology and Metabolism 89 163-168. (doi:10.1210/jc.2003-030550)

Fadda G, Basolo F, Bondi A, Bussolati G, Crescenzi A, Nappi O, Nardi F, Papotti M, Taddei G \& Palombini L 2010 Cytological classification of thyroid nodules.

Proposal of the SIAPEC-IAP Italian Consensus Working Group. Pathologica 102 405-408.

Giovanella L \& Suriano S 2011 Spurious hypercalcitoninemia and heterophilic antibodies in patients with thyroid nodules. Head \& Neck 33 95-97. (doi:10.1002/hed. 21405)

Guyetant S, Wion-Barbot N, Rousselet MC, Franc B, Bigorgne JC \& Saint-Andre JP 1994 C-cell hyperplasia associated with chronic lymphocytic thyroiditis: a retrospective quantitative study of 112 cases. Human Pathology 25 514-521. (doi:10.1016/0046-8177 (94)90124-4)

Karanikas G, Moameni A, Poetzi C, Zettinig G, Kaserer K, Bieglmayer C, Niederle B, Dudczak R \& Pirich C 2004 Frequency and relevance of elevated calcitonin levels in patients with neoplastic and nonneoplastic thyroid disease and in healthy subjects. Journal of Clinical Endocrinology and Metabolism 89 515-519. (doi:10.1210/jc. 2003-030709)

Kloos RT, Eng C, Evans DB, Francis GL, Gagel RF, Gharib H, Moley JF, Pacini F, Ringel MD, Schlumberger M et al. 2009 Medullary thyroid cancer: management guidelines of the American Thyroid Association. Thyroid 19 565-612. (doi:10.1089/thy.2008.0403)

Lima MA, Santos BM \& Borges MF 1998 Quantitative analysis of C cells in Hashimoto's thyroiditis. Thyroid $\mathbf{8}$ 505-509. (doi:10.1089/thy.1998.8.505)

Niccoli P, Conte-Devolx B, Lejeune PJ, Carayon P, Henry JF, Roux F, Wion-Barbot N \& Bigorgne JC 1996 Hypercalcitoninemia in conditions other than medullary cancers of the thyroid. Annales d'endocrinologie 57 15-21.

Papi G, Corsello SM, Cioni K, Pizzini AM, Corrado S, Carapezzi C, Fadda G, Baldini A, Carani C, Pontecorvi A et al. 2006 Value of routine measurement of serum calcitonin concentrations in patients with nodular thyroid disease: a multicenter study. Journal of Endocrinological Investigation 29 427-437.

Poppe K, Verbruggen LA, Velkeniers B, Finné E, Body JJ \& Vanhaelst L 1999 Calcitonin reserve in different stages of atrophic autoimmune thyroiditis. Thyroid 9 1211-1214. (doi:10.1089/thy.1999.9.1211)

Scheuba C, Kaserer K, Moritz A, Drosten R, Vierhapper H, Bieglmayer C, Haas OA \& Niederle B 2009 Sporadic hypercalcitoninemia: clinical and therapeutic consequences. Endocrine-Related Cancer 16 243-253. (doi:10.1677/ERC-08-0059) 
Schuetz M, Beheshti M, Oezer S, Novotny C, Paul M, Hofmann A, Bieglmayer C, Niederle B, Kletter K, Dudczak R et al. 2006 Calcitonin measurements for early detection of medullary thyroid carcinoma or its premalignant conditions in Hashimoto's thyroiditis. Anticancer Research 26 723-727.

Tabassian AR, Nylen ES, Linnoila RI, Snider RH, Cassidy MM \& Becker KL 1989 Stimulation of hamster pulmonary neuroendocrine cells and associated peptides by repeated exposure to cigarette smoke. American Review of Respiratory Disease 140 436-440. (doi:10. 1164/ajrccm/140.2.436)
Toledo SP, Lourenço DM Jr, Santos MA, Tavares MR, Toledo RA \& Correia-Deur JE 2009 Hypercalcitoninemia is not pathognomonic of medullary thyroid carcinoma. Clinics 64 699-706. (doi:10.1590/S180759322009000700015)

Received in final form 1 March 2012 Accepted 6 March 2012 Made available online as an Accepted Preprint 7 March 2012 